\title{
Studies of Paroxysmal Nocturnal Hemoglobinuria Erythro- cytes: Increased Lysis and Lipid Peroxide Formation by Hydrogen Peroxide*
}

\author{
Charles E. Mengel $\ddagger$ Herbert E. Kann, Jr.,§ and Wilhelm D. Meriwether $\|$ \\ (From the Department of Medicine, The Ohio State University, College of Medicine, \\ Columbus, Ohio)
}

\begin{abstract}
When paroxysmal nocturnal hemoglobinuria ( $\mathrm{PNH}$ ) erythrocytes were exposed to $\mathrm{H}_{2} \mathrm{O}_{2}$ they lysed excessively and formed greater than normal quantities of lipid peroxides when compared to red cells of normal subjects and patients with most types of hematologic disease. It was also shown that lytic sensitivity to acidified serum was related to the enhanced lytic sensitivity to $\mathrm{H}_{2} \mathrm{O}_{2}$. If the lipid of $\mathrm{PNH}$ cells was first extracted then exposed to ultraviolet radiation more lipid peroxides were formed than in extracts of normal red blood cells. The possible explanations for these findings and their relationship to the PNH hemolytic mechanism are discussed.
\end{abstract}

\section{Introduction}

Paroxysmal nocturnal hemoglobinuria $(\mathrm{PNH})$ is a unique hemolytic anemia characterized by accelerated intravascular hemolysis during sleep (1). Although the disease is usually considered to be acquired, an abnormality intrinsic to the red cell is responsible for hemolysis (2-6). Extensive studies have helped to define the role of complement components in lysis of $\mathrm{PNH}$ red cells $(7-11)$, but the nature of the intracorpuscular defect has not been clarified.

* Received for publication 10 November 1966 and in revised form 10 July 1967.

Presented in part before the Central Society for Clinical Research, November 1965, Chicago, Ill.

Supported by U. S. Public Health Service Research Grants CA-08699 and CA-08702, and by U. S. N. Research Contract Nonr-495 (30), and U. S. Public Health Service Training Grant CA-5192-01.

$¥$ Markle Scholar in Academic Medicine, Director, Division of Hematology and Oncology, The Ohio State University, Columbus, Ohio.

$\S$ Research Fellow, Division of Hematology and Oncology, The Ohio State University, Columbus, Ohio.

\| Research Trainee, Division of Hematology and Oncology, The Ohio State University University Hospitals, Columbus, Ohio, and Medical Student, Duke University School of Medicine, Durham, N. C.

Address requests for reprints to Dr. Charles E. Mengel, Division of Hematology and Oncology, The Department of Medicine, The Ohio State University, College of Medicine, Columbus, Ohio 43210.
We have previously described greatly enhanced in vivo $\mathrm{PNH}$ hemolytic activity after parenteral iron administration in several patients with $\mathrm{PNH}$ (12). This was presumed to reflect a unique effect of iron on $\mathrm{PNH}$ erythrocytes. Iron serves as a catalyst in the peroxidation of lipid $(13,14)$, and increased levels of lipid peroxides have been found in tissues of animals injected with iron complexes (15). Recent studies in our laboratory have shown that peroxidation of red cell lipid can occur in vivo causing damage and lysis of red cells (16). These observations led us to speculate that $\mathrm{PNH}$ red cells might be unusually sensitive to lipid prooxidants, and that lipid peroxidation might be involved in $\mathrm{PNH}$ hemolysis.

In the course of studies undertaken to investigate this possibility, it was found that (a) $\mathrm{PNH}$ red cells are abnormally susceptible to lysis by $\mathrm{H}_{2} \mathrm{O}_{2}$, an agent capable of peroxidizing lipid, and (b) under the experimental conditions cited peroxidation was induced more rapidly in lipid of $\mathrm{PNH}$ red cells than in lipid of normal red cells.

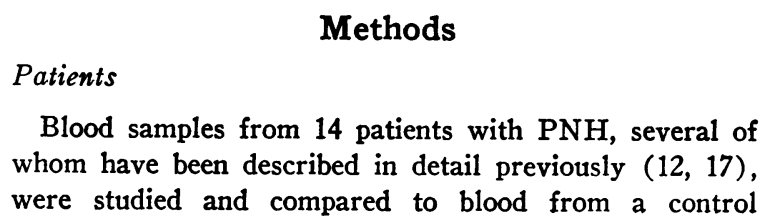


group consisting of 300 normal subjects and 100 patients with many different hematologic diseases.

Red cells from all $\mathrm{PNH}$ patients consistently lysed in acidified serum; lysis was completely prevented by heating serum at $56^{\circ} \mathrm{C}$ for $\frac{1}{2} \mathrm{hr}$. Red cell acetylcholinesterase activity was definitely lower than normal in ten, "low normal" in two, and within the normal range in two others. All but 2 patients (No. 4 and No. 7) had moderately severe hemolytic activity during the period of follow-up and study. Patients included in the control group had most types of hematologic diseases including various types of erythrocyte glucose-6-phosphate dehydrogenase (G-6-PD) deficiency, megaloblastic anemias, hemoglobinopathies, immune hemolytic anemia, aplastic and refractory anemias, and various myelo- and lymphoproliferative disorders.

\section{Studies of erythrocytes}

(a) Hemoglobin was determined as cyanmethemoglobin, hematocrits by a micro-method, and reticulocyte counts and Heinz body preparations by standard methods (8).

(b) Fresh serum, kept under oil at $\mathrm{pH} 6.2 \pm 0.1$, was used for testing acid-serum lysis (18).

(c) Erythrocyte acetylcholinesterase activity was determined using the method described by Ellman et al. (19), except that a change of absorbance of 0.001 was taken as one enzyme unit, and values were expressed as enzyme units per microliter cells per minute.

(d) Hydrogen peroxide hemolysis test. Details of the method used for determining in vitro lytic sensitivity of erythrocytes to hydrogen peroxide have been described previously $(16,20,21)$. All glassware used was washed with concentrated nitric acid and hydrogen peroxide (1000 $\mathrm{ml}$ of acid plus $5 \mathrm{ml}$ of $30 \% \mathrm{H}_{2} \mathrm{O}_{2}$ and thoroughly rinsed with thrice deionized water. Hydrogen peroxide solutions (Becco Chemical Div., FMC Corp., Buffalo, N. Y.), 2-6\%, prepared in buffer $\left(0.2 \mathrm{M} \mathrm{KH}_{2} \mathrm{PO}_{4}-0.2\right.$ $\mathrm{M} \mathrm{NaOH}$ ) at $\mathrm{pH}$ 7.4, were stored away from light at $4^{\circ} \mathrm{C}$. Each $\mathrm{H}_{2} \mathrm{O}_{2}$ solution was titrated iodometrically for actual peroxide content and readjusted to the desired concentration when necessary. Erythrocytes from defibrinated blood were made up to $2.5 \%$ suspensions (corrected for the hematocrit of packed cells) in a solution of equal volumes of buffer $\left(250 \mathrm{ml}\right.$ of $0.2 \mathrm{M} \mathrm{KH}_{2} \mathrm{PO}_{4}$ and

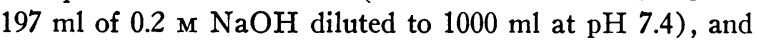
physiologic saline and were incubated for $1 \mathrm{hr}$ at $37^{\circ} \mathrm{C}$. Cells were then washed once and made up in $5 \%$ suspensions in physiologic saline. These suspensions checked by hemoglobin and red blood cell (RBC) counts were reproducible in triplicate samples of each subject and were identical for the control subject and $\mathrm{PNH}$ patients in each simultaneous study, as were the final $100 \%$ hemolysate values at the termination of the $\mathrm{H}_{2} \mathrm{O}_{2}$ lysis test. Introduction of a $20 \%$ measuring error at this point (making of $5 \%$ suspension) failed to alter significantly the eventual $\mathrm{H}_{2} \mathrm{O}_{2}$ lysis. Therefore, it was unlikely that any differences observed between control and $\mathrm{PNH}$ studies resulted from differences in amount of blood, numbers of cells, etc., exposed to $\mathrm{H}_{2} \mathrm{O}_{2}$. Quadruplicate samples of cell suspension $(0.25 \mathrm{ml})$ were then mixed with equal volumes of $\mathrm{H}_{2} \mathrm{O}_{2}$ solutions in buffer at $\mathrm{pH} 7.4$, incubated at $37^{\circ} \mathrm{C}$ for $15 \mathrm{~min}$ and then at room temperature for $2 \mathrm{hr}$ and $45 \mathrm{~min}$. Buffer blanks were carried throughout. When incubation was complete 9 volumes of saline were added to three tubes of each $\mathrm{H}_{2} \mathrm{O}_{2}$ concentration and 9 volumes of water to the fourth. After centrifugation the supernatant was read at $540 \mathrm{~m} \mu$ after conversion of hemoglobin to cyanmethemoglobin.

(e) Lipid peroxide determinations. Lipid peroxide formation in erythrocytes was determined by measuring the pink chromagen (absorbance maximum $535 \mathrm{~m} \mu$ ) formed by the reaction of 2-thiobarbituric acid (TBA) with a breakdown product of lipid peroxides, malonylaldehyde $(22,23)$. Erythrocytes were washed twice in physiologic saline. Then $0.05 \mathrm{ml}$ of red cells in $1 \mathrm{ml}$ of physiologic saline was mixed with $1 \mathrm{ml}$ of the $6 \% \mathrm{H}_{2} \mathrm{O}_{2}$ solution and incubated for $1 \mathrm{hr}$ at $37^{\circ} \mathrm{C} .1 \mathrm{ml}$ of this incubation mixture was then added to $1 \mathrm{ml}$ of $10 \%$ tricholoroacetic acid and after thorough mixing was filtered through Whatman No. 1 paper. $1 \mathrm{ml}$ of the filtrate was mixed well with $1.2 \mathrm{ml}$ of thiobarbituric acid (Eastman Organic Chemicals, Rochester, N. Y.) ( $0.67 \%$ in water) and the mixture was heated in a boiling water bath for $15 \mathrm{~min}$. After cooling to room temperature, absorption spectra were taken and the absorbance at $535 \mathrm{~m} \mu$ was recorded.

A standard absorption curve for malonylaldehyde was prepared using 1, 1, 3, 3-tetraethoxypropane (TEP) (Kay-Fries Chemicals, Inc., New York, N. Y.), a compound that hydrolyzes to 1 mole of malonylaldehyde and 4 moles of ethanol (24). An absorbance of 0.1 in the TBA reaction was calculated to be equivalent to 8 $\mathrm{m} \mu$ moles of malonylaldehyde. The results of all lipid peroxide determinations were then expressed as m mmoles of malonylaldehyde per milliliter of RBCs. We have previously discussed the advantages and limitations of the TBA test for lipid peroxides (16).

(f) Whole blood methemoglobin levels were determined spectrophotometrically (25). G-6-PD activity was determined as described by Zinkham et al. (26), except that a change of absorbance of 0.001 was taken as one enzyme unit and activities were expressed as enzyme units per microliter of cells per minute. Erythrocyte catalase activity was determined as described by Feinstein (27).

Red cell glutathione peroxidase activity was determined by a method described previously (16) and blood reduced glutathione was measured as described by Beutler et al. (28).

\section{Studies of red cell lipid}

Lipid extractions were performed simultaneously on $\mathrm{PNH}$ and normal erythrocytes in each study. Lipids were extracted from $4 \mathrm{ml}$ of thrice washed, packed erythrocytes using a modification of the method of Bligh and Dyer $(29,30)$ as described by DeGier et al. (30). After the final chloroform layer was evaporated to dryness under vacuum at $20^{\circ} \mathrm{C}$, the residue was taken up in $16 \mathrm{ml}$ of physiologic saline and used immediately. The lipid extract thus obtained was white and opalescent with no evidence of pigment tinge. Lipid phosphorus determina- 
tions were performed on each lipid extract (31). Quantities of lipid present in these extracts during simultaneous studies did not vary between control and $\mathrm{PNH}$ samples (e.g., 40.1 vs. $39.8 \mu \mathrm{g} / \mathrm{ml} ; 42.0$ vs. $42.8 \mu \mathrm{g} / \mathrm{ml}$ ). Before any sampling, the lipid extract was thoroughly agitated using a Vortex mixer. Uniformity of lipid concentration in the samples of "suspension" was established by nearly identical lipid phosphorus values obtained on multiple samples of extract after each mixing (e.g., $38.0,37,8$, and $37.0 \mu \mathrm{g}$ of $\mathrm{P} / \mathrm{ml}$ of extract).

To induce peroxidation of lipid (14), we exposed equal volumes of extracts of $\mathrm{PNH}$ and normal cells containing equal quantities of lipid simultaneously to ultraviolet radiation as follows. The lipid extracts were placed in 200-ml quartz Erhlenmeyer flasks and shaken at $100 \mathrm{cy}-$ cles/min, $40 \mathrm{~cm}$ below an ultraviolet source (two Westinghouse Sterilamps G15-T8). Lipid peroxides (TBA) were measured before and after $2 \mathrm{hr}$ exposure to UV light.

\section{Serum tocopherol assay}

Serum tocopherol levels were measured colorimetrically using 2,4,6-tripyridyl-s-triazine (TPTZ) (Baker Chemical Co., Phillipsburg, N. J.) in an assay based on the oxidimetric reduction of ferric ions by tocopherol (32). $2 \mathrm{ml}$ of serum was added to an equal volume of absolute ethanol and mixed with $2 \mathrm{ml}$ of xylene for $1 \mathrm{~min}$. A standard was prepared by adding $2 \mathrm{ml}$ of alpha tocopherol in absolute ethanol $(1.0 \mathrm{mg} / 100 \mathrm{ml})$ to $2 \mathrm{ml}$ of distilled water followed by $2 \mathrm{ml}$ of xylene with mixing. A blank was prepared by substituting $2 \mathrm{ml}$ of distilled water for the serum or plasma and mixing with $2 \mathrm{ml}$ of xylene. After centrifugation at $2500 \mathrm{rpm}$ for $5 \mathrm{~min} 1 \mathrm{ml}$ of the xylene (top layer) was transferred to a cuvette and 1 $\mathrm{ml}$ of $0.12 \%$ TPTZ in $n$-propanol added. The sample was then read against a xylene blank in a Beckman DB Spectrophotometer at $460 \mathrm{~m} \mu$. Then, $0.2 \mathrm{ml}$ of $12 \%$ $\mathrm{FeCl}_{8} \cdot 6 \mathrm{H}_{2} \mathrm{O}$ was pipeted into each cuvette, shaken, and the absorbance determined immediately at $600 \mathrm{~m} \mu$. The concentration of tocopherol in $\mathrm{mg} / 100 \mathrm{ml}$ was calculated as :

Sample abs. $600 \mathrm{~m} \mu$

- (Carotene factor $X$ sample abs. $460 \mathrm{~m} \mu)$. Std. abs. $600 \mathrm{~m} \mu$

The carotene correction factor of 0.2 was derived by comparing the absorbance of a $0.4 \mathrm{mg} / 100 \mathrm{ml}$ solution of carotene at 460 and $600 \mathrm{~m} \mu$ used in place of the xylene layer in the routine procedure. The carotene factor was consistently low so that even moderate variations in carotene, absorbance of plasma at $460 \mathrm{~m} \mu$ did not significantly affect the final results.

\section{Results}

An example of the hydrogen peroxide hemolysis study in $\mathrm{PNH}$ is shown in Fig. 1 (patient 5). This patient's red cells showed significantly greater than normal lysis at all concentrations tested. Re-

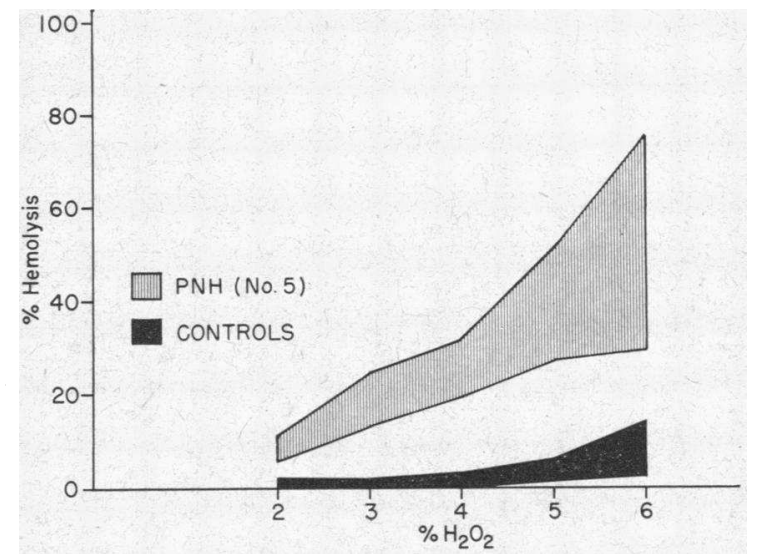

Fig. 1. IN vitro hemolysis of Human RBCs BY H YDROGEN PEROXIDE IN PATIENT 5. The normal range illustrated included duplicate determinations of 100 different control subjects. The values presented for patient 5 include the ranges obtained on 10 determinations, each performed in triplicate.

sults of the hydrogen peroxide hemolysis test in all $\mathrm{PNH}$ patients and controls are shown in Table I. In 10 patients, values were consistently and significantly elevated when compared to those of controls. In patient 2 the mean value was significantly different from the controls $(P<0.01)$, although one determination had been in the "normal range." The mean values of patients 7 and 10 were not significantly different from those of the controls, and in patient 8 the single value obtained was in the normal range. There was no significant difference in mean values between $\mathrm{PNH}$ patients that were iron deficient or iron repleted, or between those who had or had not received transfusions within 4 months prior to study. There was no consistent correlation between lytic sensitivity to $\mathrm{H}_{2} \mathrm{O}_{2}$ and the patient's clinical course, the degree of lysis in acid-serum, or the red cell acetylcholinesterase activity. In patient 9 the $\mathrm{H}_{2} \mathrm{O}_{2}$ lysis test was strongly positive at a time when the acid-serum lysis test, as performed routinely, was negative. This patient's acid-serum lysis test became positive after his iron deficiency was corrected.

As shown in Table II, PNH red cells formed significantly greater quantities of lipid peroxides than control cells during incubation with $\mathrm{H}_{2} \mathrm{O}_{2}$. No lipid peroxides could be demonstrated in $\mathrm{PNH}$ or control cells before incubation with $\mathrm{H}_{2} \mathrm{O}_{2}$. As with the $\mathrm{H}_{2} \mathrm{O}_{2}$ lysis test there was no consistent 
TABLE I

Lysis of erythrocytes by hydrogen peroxide*

\begin{tabular}{|c|c|c|c|c|}
\hline \multirow[b]{2}{*}{ Subject } & \multirow{3}{*}{$\begin{array}{c}\text { No. of observations } \\
300 \\
20\end{array}$} & \multicolumn{3}{|c|}{ Per cent lysis in $6 \% \mathrm{H}_{2} \mathrm{O}_{2}$} \\
\hline & & Mean ( \pm SD) & Range & Time span of studies \\
\hline $\begin{array}{l}\text { All controls } \\
\text { Patients with reticulocytosis } \\
\quad(10-60 \%) \text { (from control group) }\end{array}$ & & $\begin{array}{l}7 \\
6.2( \pm 1.6)\end{array}$ & $\begin{array}{l}0-10 \\
3-9\end{array}$ & 4 years \\
\hline $\begin{array}{r}\text { PNH } 1 \\
2 \\
3 \\
4 \\
5 \\
6 \\
7 \\
8 \\
9 \\
10 \\
11 \\
12 \\
13 \\
14\end{array}$ & $\begin{array}{r}60 \\
10 \\
20 \\
15 \\
14 \\
2 \\
2 \\
1 \\
6 \\
6 \\
4 \\
5 \\
5 \\
5\end{array}$ & $\begin{array}{cc}70 & \\
13 & ( \pm 2.4) \\
30 & \\
35 & \\
41 & \\
58 & \\
12 & ( \pm 4.3) \\
6 \ddagger & \\
80 & \\
10 & ( \pm 2.3) \\
17 & \\
50 & \\
17 & \\
19 & \end{array}$ & $\begin{array}{r}50-95 \\
9-16 \\
15-58 \\
12-67 \\
30-77 \\
40-76 \\
9-15 \\
74-90 \\
7-13 \\
16-18 \\
43-60 \\
14-24 \\
15-26\end{array}$ & $\begin{array}{l}3 \text { years } \\
3 \text { years } \\
3 \text { years } \\
3 \text { years } \\
2 \text { years } \\
1 \text { month } \\
1 \text { month } \\
8 \text { months } \\
6 \text { months } \\
4 \text { months } \\
4 \text { months } \\
3 \text { months } \\
2 \text { months }\end{array}$ \\
\hline
\end{tabular}

* Each determination was carried out in triplicate.

$\ddagger$ A single determination.

or definite correlation between quantities of lipid peroxides formed and iron status, transfusion status, activity of the disease, acid-serum lysis, or red cell acetylcholinesterase activity. However, in contrast to the data obtained with the hydrogen peroxide lysis test, all patients consistently had significantly elevated values.

TABLE II

Formation of lipid peroxides in erythrocytes during incubation with hydrogen peroxide*

Each determination was carried out in duplicate.

\begin{tabular}{|c|c|c|c|}
\hline & \multicolumn{3}{|c|}{ Lipid peroxides } \\
\hline & Mean & Range & $\begin{array}{c}\text { No. of } \\
\text { determinations }\end{array}$ \\
\hline & \multicolumn{3}{|c|}{ mumoles malonylaldehyde $/ \mathrm{ml}$ cells } \\
\hline $\begin{array}{l}\text { All controls } \\
\text { Patients with reticu- } \\
\text { locytosis (from } \\
\text { control group) }\end{array}$ & $\begin{array}{l}30 \\
25\end{array}$ & $\begin{array}{l}0-60 \\
0-50\end{array}$ & $\begin{array}{r}300 \\
20\end{array}$ \\
\hline $\begin{array}{r}\text { PNH } 1 \\
2 \\
3 \\
4 \\
5 \\
6 \\
7 \\
8 \\
9 \\
10 \\
11 \\
12 \\
13 \\
14\end{array}$ & $\begin{array}{l}400 \\
240 \\
260 \\
220 \\
300 \\
191 \\
128 \\
110^{*} \\
104 \\
142 \\
77 \\
335 \\
100 \\
160\end{array}$ & $\begin{array}{c}300-500 \\
180-300 \\
210-310 \\
180-260 \\
250-350 \\
126-256 \\
104-152 \\
\\
92-116 \\
132-152 \\
64-90 \\
320-350 \\
76-140 \\
100-210\end{array}$ & $\begin{array}{r}60 \\
10 \\
20 \\
15 \\
14 \\
2 \\
2 \\
1 \\
6 \\
6 \\
4 \\
5 \\
5 \\
5\end{array}$ \\
\hline
\end{tabular}

* One observation.
Freshly extracted lipid from $\mathrm{PNH}$ red cells formed greater than normal quantities of lipid peroxides during exposure to ultraviolet radiation (Table III).

Red cells of $\mathrm{PNH}$ patient 4 had normal GSH content and G-6-PD activity and all other patients had slight elevation of each, consistent with a younger than average red cell population. Glutathione peroxidase activity was within the normal range in all patients. With the exception of patient 1 , all patients had normal red cell catalase activity. The catalase activity of patient 1 was consistently in the range of $50 \%$ of normal.

Serum tocopherol assays were performed in six

TABLE III

Peroxidation of erythrocyte lipid by ultraviolet radiation*

\begin{tabular}{lccc}
\hline \hline & \multicolumn{3}{c}{ Lipid phosphorus } \\
\cline { 2 - 4 } & $\begin{array}{c}\text { Before } \\
\text { UV }\end{array}$ & \multicolumn{2}{c}{ After 2 hr UV } \\
\cline { 2 - 4 } & Mean & Range \\
\hline Controls (10) $\ddagger$ & 0 & 62 & $54-67$ \\
PNH patients & 0 & 130 & $128-132$ \\
No. 9 & 0 & 124 & 124,124 \\
No. 12 & 0 & 72 & 70,74 \\
No. 13 & & &
\end{tabular}

* Values were obtained from duplicate samples in each determination.

$\ddagger$ Included here are 7 normal subjects and 3 patients with elevated reticulocyte counts $(8-15 \%)$.

\$Each patient was studied once in duplicate, along with a known normal control. 
patients. All had levels that were within the normal range for this laboratory (Table IV). It was of note that the two patients with the greatest lytic sensitivity of $\mathrm{H}_{2} \mathrm{O}_{2}$ had the highest range of tocopherol levels.

Additional studies were carried out to explore any possible relationship between the sensitivity of $\mathrm{PNH}$ erythrocytes to acid-serum and to $\mathrm{H}_{2} \mathrm{O}_{2}$. $\mathrm{PNH}$ cells were incubated first with fresh or heatinactivated, acidified serum in the usual fashion and then washed three times and subjected to $\mathrm{H}_{2} \mathrm{O}_{2}$ lysis exactly as described previously. As shown in Table $\mathrm{V}$, cells remaining after standard acid-serum lysis (and, therefore, presumably resistant to it also) had a relative resistance to lysis by $\mathrm{H}_{2} \mathrm{O}_{2}$. Cells exposed first to heat-inactivated, acidified serum (during which no lysis of cells occurred) had no decrease of lytic sensitivity to $\mathrm{H}_{2} \mathrm{O}_{2}$. Cells remaining after acid-serum lysis were no different with respect to GSH or tocopherol content, G-6-PD, acetylcholinesterase, or catalase activity than cells exposed to unacidified serum were.

Normal and $\mathrm{PNH}$ red cells were then incubated first with $\mathrm{H}_{2} \mathrm{O}_{2}$, and subsequently subjected to the usual acid-serum lysis procedure. In these studies $10 \%$ suspensions of thrice washed red cells in physiologic saline were incubated with equal volumes of $6 \% \mathrm{H}_{2} \mathrm{O}_{2}$ for $1 \mathrm{hr}$ at $37^{\circ} \mathrm{C}$. After washing three times in physiologic saline, acid-serum lysis was determined in the usual fashion. As shown in Table VI, PNH red cells had an increase of lytic sensitivity to acid-serum after incubation with $\mathrm{H}_{2} \mathrm{O}_{2}$. Cells exposed to buffer rather than $\mathrm{H}_{2} \mathrm{O}_{2}$ as controls had no change with respect to acid-serum lysis. Heat inactivation of serum $\left(56^{\circ} \mathrm{C}\right.$ for $\left.30 \mathrm{~min}\right)$ failed to prevent acidserum lysis. Normal red cells also developed increased lytic sensitivity to acid-serum, which on
TABLE IV

Serum tocopherol levels in control and PNH patients*

\begin{tabular}{|c|c|c|}
\hline & $\mathrm{H}_{2} \mathrm{O}_{2}$ lysis & Serum tocopherol levels \\
\hline Control & $\begin{array}{c}\% \\
0-10\end{array}$ & $\begin{array}{c}m g / 100 m l \\
0.50-1.2 \quad(40)\end{array}$ \\
\hline $\begin{array}{r}\text { PNH } 9 \\
10 \\
11 \\
12 \\
13 \\
14\end{array}$ & $\begin{array}{r}74-90 \\
7-13 \\
16-18 \\
43-60 \\
14-24 \\
15-26\end{array}$ & $\begin{array}{ll}1.1-1.15 & (3) \\
0.92-1.24 & (5) \\
0.54-0.67 & (5) \\
1.0-1.09 & (3) \\
0.50 & (1) \\
1.0-1.06 & (3)\end{array}$ \\
\hline
\end{tabular}

* Range of values obtained is given and the numbers in parentheses indicate the number of determinations. Data of $\mathrm{H}_{2} \mathrm{O}_{2}$ lysis studies are included for purposes of comparison with tocopherol levels.

one occasion was completely reversed by heat inactivation of serum.

\section{Discussion}

Extensive studies have been made of the serum factors necessary for lysis of $\mathrm{PNH}$ red cells but the basic intracorpuscular abnormality has not been defined. Although the disease is generally assumed to be an acquired one, cross-transfusion studies have clearly shown that the primary defect resides within the erythrocyte (2). Erythrocyte membrane abnormalities have been described in electron microscopic studies (4-6) and varying reports of abnormalities of lipid in $\mathrm{PNH}$ erythrocytes (33-40) have appeared. However, it has been suggested that the changes observed by electron microscopy do not necessarily reflect the primary corpuscular abnormality, and there has been considerable disagreement with regard to the reported lipid abnormalities (1), the latter often due to variance of methodology.

We observed marked acceleration of hemolysis in four PNH patients on six occasions after therapeutic administration of intramuscular iron (12).

TABLE V

Lysis of $P N H$ red cells by hydrogen peroxide after exposure to acidified serum ( $p H 6.0)^{*}$

\begin{tabular}{|c|c|c|c|c|}
\hline \multirow[b]{2}{*}{ Patient } & \multirow[b]{2}{*}{$\begin{array}{l}\text { Per cent lysis in } \\
6 \% \mathrm{H}_{2} \mathrm{O}_{2} \text { before } \\
\text { acid-serum lysis }\end{array}$} & \multirow[b]{2}{*}{$\begin{array}{l}\text { Per cent lysis in } \\
\text { fresh acid-serum }\end{array}$} & \multicolumn{2}{|c|}{$\begin{array}{c}\text { Per cent lysis in } 6 \% \mathrm{H}_{2} \mathrm{O}_{2} \text { after } \\
\text { incubation with acid-serum }\end{array}$} \\
\hline & & & $\begin{array}{l}\text { Using fresh } \\
\text { serum }\end{array}$ & $\begin{array}{c}\text { Using heat- } \\
\text { inactivated serum }\end{array}$ \\
\hline $\begin{array}{l}1 \\
2 \\
3 \\
4\end{array}$ & $\begin{array}{l}87 \\
12 \\
22 \\
24\end{array}$ & $\begin{array}{l}50 \\
35 \\
30 \\
15\end{array}$ & $\begin{array}{r}47 \\
1 \\
15 \\
14\end{array}$ & $\begin{array}{l}85 \\
11 \\
24 \\
25\end{array}$ \\
\hline
\end{tabular}

* Values given represent the means of duplicate determinations in single experiments. 
TABLE VI

Lysis of normal and $P N H$ red cells in acidified serum before and after incubation with hydrogen peroxide*

\begin{tabular}{lccc}
\hline \hline & \multicolumn{3}{c}{ Per cent lysis in acid-serum } \\
\cline { 2 - 4 } & & \multicolumn{2}{c}{ After $\mathrm{H}_{2} \mathrm{O}_{2}$} \\
\cline { 2 - 4 } & $\begin{array}{c}\text { Before } \\
\mathrm{H}_{2} \mathrm{O}_{2}\end{array}$ & $\begin{array}{r}\text { Using } \\
\text { fresh } \\
\text { serum }\end{array}$ & $\begin{array}{c}\text { Using } \\
\text { heat- } \\
\text { inactivated } \\
\text { serum }\end{array}$ \\
\hline PNH patient & & & \\
No. 2 & 31 & 58 & 47 \\
PNH patient & 15 & 50 & 40 \\
No. 4 & 13 & 56 & 27 \\
& 12 & 47 & 26 \\
& 13 & 45 & 11 \\
Normal red cells & 0 & 30 & 0 \\
& 0 & 58 & 60 \\
& 0 & 35 & 40 \\
& 0 & 15 & 8 \\
\hline
\end{tabular}

* Values given represent means of duplicate determinations in single experiments.

To our knowledge, hemolysis after iron administration has been observed only in patients with $\mathrm{PNH}$. Our speculation that the accelerated hemolysis might have been related to peroxidation of red cell lipid was based on the following facts: (a) one of the known actions of iron is its role as a catalyst in this reaction $(14) ;(b)$ increased levels of lipid peroxides have been found in tissues of animals given iron in excess $(15) ;(c)$ iron toxicity in animals has been prevented by administration of a specific lipid antioxidant (41) (tocopherol); and $(d)$ peroxidation of unsaturated fatty acids in red cells has been known to occur in vitro, and recent studies in this laboratory have established the fact that this reaction can also occur in vivo and result in red cell damage and lysis (16). The present studies have shown that PNH erythrocytes also have increased lytic sensitivity to an agent capable of peroxidizing lipid. Since serum was not present in the system using washed red cells and the $\mathrm{pH}$ was maintained at 7.4 , it is unlikely that the enhanced lysis reflected any immediate interaction with complement. These studies have also shown that lipid, both in intact red cells and in extracts of $\mathrm{PNH}$ erythrocytes, is capable of forming peroxides more quickly than lipid of normal red cells.

The mechanism for increased lytic sensitivity and lipid peroxide formation in $\mathrm{PNH}$ red cells exposed to a peroxidizing agent has not been established.
A similar increase in lytic sensitivity of red cells to $\mathrm{H}_{2} \mathrm{O}_{2}$ has been observed in newborns (42), in patients with malabsorption (43), in acanthocytosis (44), and in experimentally induced tocopherol deficiency in man (45). In each of these settings the enhanced peroxide lysis has presumably reflected the effect of tocopherol deficiency. None of the $\mathrm{PNH}$ patients in our present series had concomitant illnesses known to be associated with tocopherol deficiency (e.g. malabsorption). and in the six patients tested, serum tocopherol levels were normal. Therefore, enhanced peroxide lysis in our patients was probably not a result of absolute tocopherol deficiency per se. Unusual $\mathrm{RBC}$ binding or content of tocopherol might cause increased peroxide sensitivity and studies of this possibility are currently in progress.

Lack of adequate catalase activity may also render red cells susceptible to the lytic effect of exogenously added hydrogen peroxide (46). Red cells from only one of our patients were relatively low in catalase activity and this could not be an explanation for increased $\mathrm{H}_{2} \mathrm{O}_{2}$ lysis in the others. No abnormalities suggesting defects of other oxido-reduction transformations were apparent in any of the patients.

There are no data available to suggest that increased lysis and lipid peroxidation reflected the effect of some excessive prooxidant. Although the iron status of $\mathrm{PNH}$ patients probably does influence their disease activity, excessive iron could not explain these results unless related to increased levels of plasma hemoglobin or other breakdown products. No correlation existed, however, between $\mathrm{H}_{2} \mathrm{O}_{2}$ lysis and clinical hemolytic activity or between $\mathrm{H}_{2} \mathrm{O}_{2}$ lysis and status of iron stores. Similar alterations could also influence the rate of peroxidation of lipid in red cells. There were no obvious color differences in lipid extracts of normal and PNH RBCs and two of the three lipid extract studies of $\mathrm{PNH}$ RBCs reported herein were from iron-depleted PNH patients. It is still possible that as yet unidentified products capable of catalyzing peroxidation of lipid were present in the lipid. An alternative possiblity, for which no data are as yet available, is that the lpid contained less antioxidant.

Although these latter considerations are possible and merit thorough investigation, it is equally possible that enhanced lysis and lipid peroxide 
formation by hydrogen in $\mathrm{PNH}$ red cells reflect an alteration of the lipids themselves. This could be an abnormality of lipid composition with an increase in unsaturated fatty acids, an altered exchange or binding of lipid to RBCs, an alteration of lipoprotein interactions, or an altered binding capacity with respect to prooxidants (such as iron, heme pigments, etc.) or antioxidants ( such as tocopherol or - $\mathrm{SH}$ compounds). The lipid content of PNH cells has been the subject of considerable discussion, study, and speculation. Some studies have reported that $\mathrm{PNH}$ red cells contained greater than normal amounts of unsaturated fatty acids $(37,39)$; other studies have not corroborated these findings $(38,40)$. Regardless of whether or not PNH red cells contain increased amounts of unsaturated fatty acids, the results of our studies have clearly established that, under the conditions cited herein, lipid of $\mathrm{PNH}$ red cells is behaviorally different from that of normal red cells with regard to lipid peroxidation. Recent, preliminary studies in our laboratory have suggested that $-\mathrm{SH}$-induced oxidations involving red cell lipids and/or protein may be involved in producing the $\mathrm{PNH}$ hemolytic defect (47).

The exact relationship of lipid peroxidation to red cell damage in vitro has not been defined. Two major possibilities exist. Hemolysis might occur as a direct consequence of peroxidation of unsaturated fatty acids in erythrocyte membranes. Peroxidation followed by rupture of double bonds in carbon chains could lead to anatomic defects in the cell membrane with subsequent alteration of permeability characteristics and eventual cell lysis. This mechanism has been postulated in lysis of mitochondria (48), and microsomes (49) under specific conditions. Alternatively, lysis could reflect a secondary effect of lipid peroxide formation, since the damaging effect of lipid peroxides on proteins, enzymes, and metabolic pathways has been well documented (50-52). With regard to this possibility, we have observed decreased activity of erythrocyte acetylcholinesterase (presumed to be a sulfhydryl-bearing enzyme) in dogs exposed to oxygen under high pressure (53), and have established the fact that this change was an effect of lipid peroxides (54).

We have speculated that inhibition by lipid peroxides might also be the mechanism responsible for the low acetylcholinesterase activity of $\mathrm{PNH}$ red cells (55). This speculation was strengthened by our previous studies of a patient who did not have PNH but whose red cells were lysed excessively by $\mathrm{H}_{2} \mathrm{O}_{2}(21)$. This man, who suffered a transient hemolytic anemia after brief exposure to oxygen under high pressure (presumably on the basis of lipid peroxidation), also had transient lowering of his RBC acetylcholinesterase activity, and he developed a positive acid-serum lysis test during the hemolytic episode. Otherwise, this patient was hematologically normal, and after recovery from hemolysis only the abnormal peroxide lysis persisted.

Additional support for a link between acidserum lysis and peroxidation of red cell lipid was obtained in the present studies. That cells remaining after acid-serum lysis (and, therefore, presumably resistant to it) were less sensitive to the lytic effect of hydrogen peroxide suggested that a similar population of cells was being destroyed by both. The observation that lysis in acidified serum was increased after incubation with hydrogen peroxide also linked peroxidation of red cell lipid and in vitro $\mathrm{PNH}$ lysis. The failure of heat inactivation of serum to reverse completely the lytic effect of acid-serum on $\mathrm{H}_{2} \mathrm{O}_{2}$ incubated $\mathrm{RBCs}$ suggested that the degree of red cell damage which had occurred during $\mathrm{H}_{2} \mathrm{O}_{2}$ incubation was greater than that which occurs in $\mathrm{PNH}$, or that another type of defect (not complement sensitive) had been produced in the red cell. It was of interest that normal cells incubated with $\mathrm{H}_{2} \mathrm{O}_{2}$ showed increased lytic sensitivity to acidserum although on only one occasion was this completely prevented by prior heat inactivation of serum.

The data reported in these studies are consistent with the hypothesis that abnormal behavior of red cell lipid, characterized by a tendency toward peroxidation of unsaturated fatty acids in membrane and stroma, is an underlying alteration of the $\mathrm{PNH}$ red cell which renders it susceptible to damage and lysis.

\section{Acknowledgments}

The author acknowledges the technical assistance of Mrs. Betty Horton, Mrs. Devinia Jefferson, and Miss Rose Marie Husney. 


\section{References}

1. Hartman, R. C., and D. E. Jenkins, Jr. 1965. Paroxysmal nocturnal hemoglobinuria: Current concepts of certain pathophysiologic features. Blood. 25: 850.

2. Dacie, J. V., and P. L. Mollison. 1949. Survival of transfused erythrocytes from a donor with nocturnal hemoglobinuria. Lancet. 1: 390.

3. Lewis, S. M., L. Syur, and J. V. Dacie. 1960. The pattern of erythrocyte destruction in hemolytic anemia, as studied with radioactive chromium. Brit. J. Haematol. 6: 122.

4. Braunsteiner, J., E. Gisinger, and F. Pakesch. 1956. Confirmation of structural abnormality in stroma of erythrocytes from paroxysmal nocturnal hemoglobinuria $(\mathrm{PNH})$ after hemolysis in distilled water. Blood. 11: 753 .

5. Cecchi, E., and E. Conestabile. 1957. Paroxysmal nocturnal hemoglobinuria: Electron-microscopic study of red blood cells. Lancet. 2: 466.

6. Lewis, S. M., D. Danon, and Y. Marikovsky. 1965. Electron-microscope studies of the red cell in paroxysmal nocturnal hemoglobinuria. Brit. J. Haematol. 11: 689.

7. Yachnin, S., M. T. Laforet, and F. H. Gardner. 1961. pH-dependent hemolytic systems. I. Their relationships to paroxysmal nocturnal hemoglobinuria. Blood. 17: 83.

8. Crosby, W. H. 1953. Paroxysmal nocturnal hemoglobinuria: Plasma factors of the hemolytic system. Blood. $8: 444$.

9. Yachnin, S., and J. M. Ruthengerg. 1965. The initiation and enhancement of human red cell lysis by activators of the first component of complement and by first component esterase: Studies using normal red cells and red cells from patients with paroxysmal nocturnal hemoglobinuria. J. Clin. Invest. $44: 518$.

10. Jenkins, D. E., Jr., W. N. Christenson, and R. L. Engle, Jr. 1962. Erythrocyte complement coating in the acid hemolysin and thrombin tests of paroxysmal nocturnal hemoglobinuria. Blood. 20: 788. (Abstr.)

11. Rosse, W. F., and J. V. Dacie. 1966. Immune lysis of normal human and paroxysmal nocturnal hemoglobinuria (PNH) red blood cells. II. The role of complement components in the increased sensitivity of PNH red cells to immune lysis. J. Clin. Invest. $45: 749$.

12. Mengel, C. E., H. E. Kann, Jr., and B. W. O'Malley. 1965. Increased hemolysis after intramuscular iron administration in patients with paroxysmal nocturnal hemoglobinuria. Blood. 26: 74.

13. Hunter, F. E., Jr., J. M. Gebicki, P. E. Hoffstein, J. Weinstein, and A. Scott. 1963. Swelling and lysis of rat liver mitochondria induced by ferrous ions. J. Biol. Chem. 238: 828 .
14. Ottolenghi, A. 1959. Interaction of ascorbic acid and mitochondrial lipides. Arch. Biochem. Biophys. $79: 355$.

15. Goldberg, L., L. E. Martin, and A. Batchelor. 1962. Biochemical changes in the tissues of animals injected with iron. J. Biochem. 83: 291.

16. Mengel, C.E., and H. E. Kann, Jr. 1966. Effects of in vivo hyperoxia on erythrocytes. II. In vivo peroxidation of erythrocyte lipid. J. Clin. Invest. 45: 1150.

17. Mengel, C. E., B. N. Hyman, B. W. O'Malley, and D. A. Howell. 1964. Coexistent paroxysmal nocturnal and cold hemoglobinuria preceded by aplastic anemia: A case report and family study. Blood. 24: 451.

18. Cartwright, G. E. 1958. Diagnostic Laboratory Hematology. Grune and Stratton, Inc., New York. 2nd edition.

19. Ellman, G. L., K. D. Courtney, A. Valentino, Jr., and R. M. Featherstone. 1961. A new and rapid colorimetric determination of acetylcholinesterase activity. Biochem. Pharmacol. 7: 88.

20. Mengel, C. E., H. E. Kann, Jr., W. W. Smith, and B. D. Horton. 1964. Effects of in vivo hyperoxia on erythrocytes. I. Hemolysis in mice exposed to hyperbaric oxygenation. Proc. Soc. Exptl. Biol. Med. 116: 259.

21. Mengel, C. E., H. E. Kann, Jr., A. Heyman, and E. Metz. 1965. Effects of in vivo hyperoxia on erythrocytes. II. Hemolysis in a human after exposure to oxygen under high pressure. Blood. 25: 822.

22. Donnan, S. K. 1950. The thiobarbituric acid test applied to tissues from rats treated in various ways. J. Biol. Chem. 182: 415.

23. Sinnhuber, R. O., T. C. Yu, and T. C. Yu. 1958. Characterization of the red pigment formed in the 2-thiobarbituric acid determination of oxidative rancidity. Food Res. 23: 626.

24. Sinnhuber, R. O., and T. C. Yu. 1958. 2-thiobarbituric acid method for the measurement of rancidity in fishery products. II. The quantitative determination of malonaldehyde. Food Technol. 12: 9.

25. Townes, P. L., and G. R. Lovell. 1961. Hereditary methemoglobinemia: A new variant exhibiting dominant inheritance of methemoglobin A. Blood. 18: 18.

26. Zinkham, W. H., R. E. Lenhard, and B. Childs. 1958. A deficiency of glucose-6-phosphate dehydrogenase activity in erythrocytes from patients with favism. Bull. Johns Hopkins Hosp. 102: 169.

27. Feinstein, R. N. 1949. Perborate as substrate in a new assay of catalase. J. Biol. Chem. 180: 1197 .

28. Beutler, E., O. Duron, and B. M. Kelly. 1963. Improved method for the determination of blood glutathione. J. Lab. Clin. Med. 61: 882.

29. Bligh, E. G., and W. J. Dyer. 1959. A rapid method of total lipid extraction and purification. Can.J. Biochem. Physiol. 37 : 911. 
30. DeGier, J., L. L. M. Van Deenen, M. C. Verloop, and C. van Gastel. 1964. Phospholipid and fatty acid characteristics of erythrocytes in some cases of anemia. Brit. J. Haematol. 10: 246.

31. Lowry, O. H., N. R. Roberts, K. Y. Leiner, M. L. $\mathrm{Wu}$, and A. L. Farr. 1954. The quantitative histochemistry of brain. I. Chemical methods. $J$. Biol. Chem. 207: 1.

32. Martinek, R. G. 1964. Method for the determination of Vitamin $\mathrm{E}$ (total tocopherols) in serum. Clin. Chem. 10: 1078.

33. Barry, R. M. 1959. The phospholipid distribution in the erythrocytes in paroxysmal nocturnal hemoglobinuria. Brit. J. Hacmatol. 5: 212.

34. Bradlow, B. A., J. Lee, and R. Rubenstein. Erythrocyte phospholipids: Quantitative thin-layer chromatography in paroxysmal nocturnal hemoglobinuria and hereditary spherocytosis. Brit. J. Haematol. 11 : 315.

35. DeGier, J., L. L. M. Van Deenen, M. C. Verloop, and C. van Gastel. 1964. Phospholipid and fatty acid characteristics of erythrocytes in some cases of anaemia. Brit. J. Haematol. $10: 246$.

36. Formijne, P., N. J. Poulie, and J. A. Rodbard. 1957. Determination of phospholipid fractions in the human erythrocytes. Clin. Chim. Acta. 2: 25.

37. Harris, I. M., T. A. J. Prankerd, and M. P. Westerman. 1957. Abnormality of phospholipids in red cells of patients with paroxysmal nocturnal haemoglobinuria. Brit. Med. J. 2: 1276.

38. Leibetseder, F., and E. H. Ahrens, Jr. 1959. The fatty-acid composition of red cells in paroxysmal nocturnal haemoglobinuria. Brit. J. Haematol. 5 : 356.

39. Munn, J. I., and W. H. Crosby. 1957. Paroxysmal nocturnal hemoglobinuria. Evidence of defect of red cell stroma manifested by abnormalities of lipids. Proc. Soc. Exptl. Biol. Med. 96: 480.

40. Phillips, G. B., and N. S. Roome. 1962. Quantitative chromatographic analysis of the phospholipids of abnormal human red blood cells. Proc. Soc. Exptl. Biol. Med. 109: 360.

41. Tollerz, G., and N. Lannek. 1966. Protection against iron toxicity in vitamin E-deficient piglets and mice by vitamin $\mathrm{E}$ and synthetic antioxidants. Nature. 201 : 846.

42. Nitowsky, H. M., M. Cornblath, and H. H. Gordon. 1956. Studies of tocopherol deficiency in infants and children. II. Plasma tocopherol and erythrocyte hemolysis in hydrogen peroxide. A.M.A.J. Diseases Children. 92: 164.

43. Binder, H. J., D. C. Herting, V. Hurst, S. C. Finch, and H. M. Spiro. 1965. Tocopherol deficiency in man. New Engl. J. Med. 273: 1289.

44. Silber, R., and H. J. Kayden. 1965. Vitamin E deficiency and autohemolysis in acanthocytosis. Blood. 26: 895. (Abstr.)

45. Horwitt, M. K., C. C. Harvey, G. D. Duncan, and W. C. Wilson. 1965. Effects of limited tocopherol intake in man with relationships to erythrocyte hemolysis in lipid oxidations. Am. J. Clin. Nutr. 4: 408.

46. Jacob, H. S., S. H. Ingbar, and J. H. Jandl. 1965. Oxidative hemolysis and erythrocyte metabolism in hereditary acatalasia. J. Clin. Invest. $44: 1187$.

47. Kann, H. E., Jr., C. E. Mengel, and W. D. Meriwether. 1966. Alteration of normal RBCs by -SH compounds: Clue to the intracorpuscular abnormality in paroxysmal nocturnal hemoglobinuria $(\mathrm{PNH})$. Clin. Res. 14: 319. (Abstr.)

48. Hunter, F. E., Jr., A. Scott, P. E. Hoffsten, J. M Gebicki, J. Weinstein, and A. Schneider. 1964. Studies of the mechanism of swelling, lysis, and disintegration of isolated liver mitochondria exposed to mixtures of oxidized and reduced glutathione. J. Biol. Chem. 239: 614 .

49. Hunter, F. E. Jr., A. Scott, P. E. Hoffsten, F. Guerra, J. Weinstein, A. Schneider, B. Shutz, J. Fink, L. Ford, and E. Smith. 1964. Studies on the mechanism of ascorbate-induced swelling and lysis of isolated liver mitochondria. J. Biol. Chem. 239: 604.

50. Baker, N., and L. Wilson. 1963. Inhibition of tumor glycolysis by hydrogen peroxide formed from autooxidation of unsaturated fatty acids. Biochem. Biophys. Res. Commun. 11: 60 .

51. Desai, I. D., and A. L. Tappel. 1963. Damage to proteins by peroxidized lipids. J. Lipid Res. 4: 204.

52. Lewis, S. E., and E. D. Wills. 1962. The destruction of $-\mathrm{SH}$ groups of proteins and amino acids by peroxides of unsaturated fatty acids. Biochem. Pharmacol. 11 : 901.

53. Zirkle, L. G., Jr., C. E. Mengel, S. A. Butler, and R. Fuson. 1965. Effects of in vivo hyperoxia on erythrocytes. IV. Studies in dogs exposed to hyperbaric oxygenation. Proc. Soc. Exptl. Biol. Med. 119: 833.

54. O'Malley, B. W., C. E. Mengel, W. D. Meriwether, and L. G. Zirkle, Jr. 1966. Inhibition of erythrocyte acetylcholinesterase by peroxides. Biochemistry. 5: 40 .

55. Mengel, C. E., and H. E. Kann, Jr. 1966. A role of lipid peroxidation in $\mathrm{PNH}$ hemolysis and its relationship to low acetylcholinesterase (AChE) activity. Clin. Res. 14:92. (Abstr.) 